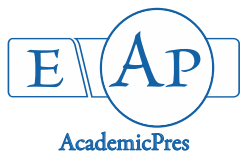

Osman MEH et al. (2020)

Notulae Scientia Biologicae 12(2):433-446

DOI: $10.15835 / \mathrm{nsb} 12210580$

Research Article

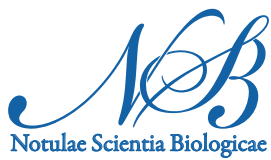

\title{
Using two plant growth promoting bacteria to sustainably thedrought-induced loss in Triticum aestivum yield
}

\author{
M. E. H. OSMAN ${ }^{1}$, Wedad A. KASIM ${ }^{1 *}$, Nabil A. OMAR², \\ Samar E. SALAMA ${ }^{2}$ \\ Tanta University, Faculty of Science, Botany Department, El-Geish Street, Tanta, \\ Egypt; elanwar_osman@yahoo.com; wedkasim@yahoo.com (*correspondingauthor) \\ ${ }^{2}$ Agriculture Research Centre, Soils, Water and Environment Research Institute, Microbiology Department, El-Gamaa Street, Giza, \\ Egypt;nabilomarster@gmail.com; Samarsalama7@yahoo.com
}

\begin{abstract}
In a greenhouse experiment, the inoculated and uninoculated grains with Azospirillum brasilense NO40 or Stenotrophomonas maltophilia were sown in unsterilized sandy soil and watered normally till the $8^{\text {th }}$ day. Thereafter, the drought stress was initiated by watering pots once every 10 days while the unstressed pots were irrigated normally once every 5 days. Samples of spikes and dry grains were collected after 120 days from sowing. The results indicated that the inoculated-drought-stressed plants maintained significantly higher values of all of the measured yield parameters, where the yielded grains had higher amounts of the direct reducing sugars, sucrose, starch; lower contents of total soluble proteins and the total free amino acids, and altered protein patterns compared to those of the uninoculated-drought-stressed plants. SDS-PAGE of the yielded grains showed that drought led to the appearance of some newly synthesized stress protein bands and disappearance of others. Inoculation with PGPB resulted in the re-appearance of some of the disappearing bands and the synthesis of new others. Meanwhile, wheat inoculation under normal conditions resulted in significantly promoted grain yields with higher contents of carbohydrates, total soluble proteins and total free amino acids than that of the uninoculated control. It has been proved that treating wheat plants with the PEG-tolerant Azospirillum brasilense NO40 or Stenotrophomonas maltophilia that were compatible with the systems into which they were introduced and possess multiple plant growth promoting traits, can be an efficient strategy to enhance wheat growth and productivity, not only under normal conditions, but also under drought stress.
\end{abstract}

Keywords: Azospirillum brasilense NO40; carbohydrate; protein patterns; soluble proteins; Stenotrophomonas maltophilia; Triticum aestivum; wheat; yield criteria

\section{Introduction}

Wheat (Triticum aestivum L.) is the most important grain crop in Egypt, representing almost 10\% of the total agricultural production, $20 \%$ of all agricultural imports, and more than $60 \%$ of the imported grains (FAO and EBRD, 2015). Furthermore, Egypt is the world's largest importer of wheat (FAO and EBRD, 2015; 
FAS/USDA, 2018). One of the key strategic targets is to sustainably maximize the economic return per unit of land and water in general, and for wheat in particular, in order to cope with the food demands of the rapidly growing population, that on average, over a quarter of it lives under the poverty line, with hopefully no or with minimal expansion in imports, especially with the significant depreciation in the Egyptian Pound against the abrupt rise in the world wheat prices (FAO and EBRD, 2015; WFP/EB, 2018). However, achieving this target has become more challenging due to the current and aggravating fresh water shortage (FAO, 2015; OED/FAO, 2018).

Egypt is a water-poor country where the fresh water resources are limited: fixed quota of Nile water (the main source), shallow groundwater reservoirs and small amounts of rainfall (FAO-Aquastat, 2018), with projections suggesting that by 2025, Egypt will reach the absolute water scarcity $\left(500 \mathrm{~m}^{3} /\right.$ capita/year) (MIWR, 2014), and by 2050, Egypt will be at sever water stress (Damania et al., 2017). In addition to being limited, the water resources are deteriorating: in quality due to the alarming levels of water pollution by the untreated sewage, industrial effluents, and agricultural runoff laden with fertilizers (WB, 2017), and in quantity due to the heavy consumption by the ever-increasing population, and by the presence of much irrigated agriculture (Mekonnen and Hoekstra, 2016), and due to the complicated relationships with the Nile Basin states (OED/FAO, 2018). Moreover, the ongoing climate change is predicted to increase the variability and uncertainty about the timing and intensity of rainfall, and to elevate temperatures which in turn will lead to higher evapotranspiration rates and more crop water requirements (MSEA, 2010; FAO, 2015; WB, 2017). Thus, to secure enough wheat for the fast-growing population of Egypt, high yields of wheat must be sustained, but with less amounts of water.

However, the lack of adequate moisture, i.e. drought stress, permanent or temporary, can cause significant damage for the plant at any developmental stage, hence, drought has been known as the most important limiting factor for crop growth and productivity worldwide (Daryanto et al., 2017). The droughtinduced yield loss varies depending on the plant species, genotype, age and developmental stage; organ or cell identity; the stress severity, duration and progression rate; and on the surrounding conditions (De Leonardis et al., 2012; Claeys et al., 2014; Ngara and Ndimba, 2014).

The beneficial soil microbes such as the plant growth promoting bacteria (PGPB) have been welcomed as a relatively simple, low-cost, environmentally sustainable solution for improving the crops' tolerance to drought stress, and therefore reducing the drought-mediated yield losses (Singh and Singh, 2013; Ngumbi and Kloepper, 2016). PGPB can induce physical and chemical changes in plants that result in enhanced tolerance to abiotic stress; these changes have been termed induced systemic tolerance (IST) by Yang et al. (2009).

In our previous study (Omar et al., 2017) two PGPB (Azospirillum brasilense NO40 and Stenotrophomonas maltophilia) were selected as promising candidates for enhancing the drought tolerance of wheat plants, because both of them were able to fix atmospheric nitrogen and to maintain high growth at different PEG6000 concentrations (up to 30\%). In our subsequent_study, they enhanced the growth of wheat seedlings under drought stress (17 days of ceasing irrigation) and induced significant recovery (10 days of reirrigation) for the seedlings represented by higher fresh and dry masses, water contents and survival (Salama, 2019). Similarly, Omar et al. (2017) found that these microbes: 1) tolerated PEG concentrations up to 50\%; 2) possessed multi plant growth promoting traits $\left(\mathrm{N}_{2}\right.$ fixation, ACC-deaminase activity, P-solubilization and production of HCN, ammonia, and phytohormones (IAA, GA and ABA));3) maintained these traits in PEGcontaining cultures; and 4) enhanced the growth of wheat seedlings growing in vitro, in a sterilized system (spermosphere model) under normal and PEG-stressed conditions.

The objective of the current study was to determine whether the positive impact of these PGPB will last till the yield stage or not? And if yes, how far these strains can diminish the drought-induced loss in wheat yield? 


\section{Materials and Methods}

\section{Plant material}

Grains of wheat (Triticum aestivum L.) cultivar 'Gemiza9' (G9) were obtained from the Wheat Department, Field Crops Research Institute, Agriculture Research Center (ARC), Giza, Egypt. 'Gemiza9' is a relatively drought-sensitive, but high-yielding, rust-resistant and wide-cultivating cultivar (El-Shami et al., 2000).

\section{Microorganisms}

The used PGPB were Azospirillum brasilense NO40 $\left(\mathrm{B}_{1}\right)$ and Stenotrophomonas maltophilia $\left(\mathrm{B}_{2}\right)$ isolated from rice (Omar et al., 1989) and wheat rhizosphere (Omar et al., 2017), respectively. They were allowed to grow in nutrient broth for $24 \mathrm{~h}$ at $28^{\circ} \mathrm{C}$ with shaking, thereafter, the culture turbidity was adjusted to $0.3 \sim 10^{8} \mathrm{CFU} / \mathrm{ml}$ (using the spectrophotometer at $600 \mathrm{~nm}$ ) to be used either for grain coating or liquid inoculation. For the grain coating, $30 \mathrm{ml}$ of each culture was taken to inoculate bags of vermiculite carrier (50 $\mathrm{g} / \mathrm{bag}$ ) and incubated for $24 \mathrm{~h}$, while for the liquid the fresh cultures were mixed with the irrigation water 20 $\mathrm{ml} /$ pot immediately after sowing, on the $8^{\text {th }}$ day from sowing (just prior of drought initiation), after two months and after three months from sowing.

\section{Plant growth and treatments}

The experiment was conducted at the Experimental Green house of Wheat Department, Field Crops Research Inst., (ARC), Giza, Egypt, using sandy soil obtained from the Agricultural Research Station, Ismailia, ARC, Giza, Egypt. Its characters and composition are illustrated in Table 1. The wheat grains were selected for apparent uniformity of shape and size, surface- sterilized by $\mathrm{HgCl}_{2} 0.1 \%$ for 5 minutes and rinsed 5 times with sterile tap water. Then, the grains were mixed with the inoculated carrier bags and Arabian gum solution on clean plastic sheets and left to be air dried for one hour in shadow before sowing. For the uninoculated treatments, a clean nutrient broth was added instead.

The experiment included 6 treatments $\times 8$ replica as follows: 1) Cont. $=$ unstressed-uninoculated control, 2) $\mathrm{B}_{1}=$ unstressed and inoculated with $A$. brasilense $\left.\mathrm{NO} 40,3\right) \mathrm{B}_{2}=$ unstressed and inoculated with $S$. maltophilia, 4) $\mathrm{D}=$ drought-stressed-uninoculated, 5) $\mathrm{DB}_{1}=$ drought-stressed and inoculated with $A$. brasilense $\mathrm{NO} 40$ and 6) $\mathrm{DB}_{2}=$ drought-stressed and inoculated with $S$. maltophilia.

Seven inoculated or uninoculated grains were sown per pot $(25 \mathrm{~cm}$ height $\times 30 \mathrm{~cm}$ diameter containing $9 \mathrm{~kg}$ of soil) and were reduced to 5 plants/ pot after one month from sowing. The pots were left to grow at 20 $\pm 2{ }^{\circ} \mathrm{C}$ in a relative humidity of $65 \%$ and $16 \mathrm{~h}$ photoperiod at $450 \mu \mathrm{mol} \mathrm{m} \mathrm{m}^{-2}$ light intensity and watered with $70 \%$ of soil field capacity (SFC) a day after day till the $8^{\text {th }}$ day. Up to this point, the drought stress was initiated by watering pots once every 10 days while the unstressed pots were irrigated normally once every 5 days. The mineral fertilizer (N, P and K) was applied according to the recommendations of the Egyptian Ministry of Agriculture.

Table 1. Some chemical and physical characteristics of the soil

\begin{tabular}{|c|c|c|c|c|c|c|c|c|c|c|c|}
\hline \multirow{2}{*}{$\mathrm{pH}$} & $\begin{array}{c}\text { EC } \\
(\mathrm{dS} / \mathrm{m})\end{array}$ & \multicolumn{3}{|c|}{$\begin{array}{c}\text { Structure } \\
\%\end{array}$} & \multicolumn{4}{|c|}{$\begin{array}{c}\text { Mineral composition } \\
(\mathrm{mg} / \mathrm{Kg} \text { soil })\end{array}$} \\
\hline \multirow{2}{*}{7.72} & \multirow{2}{*}{0.50} & Sand & Silt & Clay & $\mathrm{N}$ & $\mathrm{P}$ & $\mathrm{K}$ & $\mathrm{Fe}$ & $\mathrm{Mn}$ & $\mathrm{Zn}$ & $\mathrm{Cu}$ \\
\cline { 3 - 26 } & 89.4 & 7.60 & 3.00 & 15.10 & 4.85 & 60.80 & 5.30 & 0.92 \\
\hline
\end{tabular}

\section{Sampling and parameters}

Samples were collected after 120 days from sowing. Firstly, some productivity criteria were determined such as the percentage of spike formation/pot, spike weight $(\mathrm{g})$, percentage of grain filling/plant, weight of grains/plant $(\mathrm{g})$ and weight of 100 grains $(\mathrm{g})$. Thereafter, the carbohydrate contents of the yielded grains were 
estimated quantitatively using the methods described by Nelson (1944) and modified by Naguib (1963), while the contents of the total soluble proteins (TSPs) and the total free amino acids (TFAAs) were determined according to Bradford (1976) and Lee and Takahashi (1966), respectively. Moreover, the protein pattern of the yielded grains was studied using one dimensional Sodium- Dodecyl Sulphate Poly Acrylamide Gel Electrophoresis (SDS-PAGE) as described by Laemmli (1970). The gel bands' scanning was analyzed by the Gel Documentation System which determines molecular mass (MM) in $\mathrm{kDa}$ of each polypeptide band in relation to a standard marker (M) using Gel Proanalyzer version 3 Media Cybernetics Imaging Exports software (Gel Doc. 2001 BioRad System).

\section{Statistical analysis}

All analytical determinations were replicated at least three times and the presented data are the mean values. The obtained results were subjected to one analysis of variance ANOVA analysis to determine the significance between treatments using CoStat software (CoHort software, California, USA, 1998).

\section{Results}

\section{Yield criteria}

The results show that drought stress caused significant reductions in the percentage of spike formation, weight of spike, percentage of grain filling, weight of grains per spike and weight of 100 grains (Table 2). Clearly, the reductions were greater in the uninoculated- drought-stressed plants (D) than in the A. brasilense NO40 or S. maltophilia-inoculated-stressed ones. The percentages of spike formation and grain filling of the droughtstressed plants were raised by both strains to 99 and to $\geq 76 \%$, compared with 86 and $47 \%$, respectively in the uninoculated-stressed treatment (D). Also, the inoculated-drought-stressed plants had higher weights of spikes by about 2 folds of their uninoculated counterpart (treatment $\mathrm{D}$ ). Due to the drought stress, the weight of grains per spike was declined by $76 \%$ in respect to the well-irrigated control; however, this decline was significantly controlled to only $24 \%$ in case of inoculation with $A$. brasilense NO 40 and to $44 \%$ in the plants which were treated with $S$. maltophilia. Similarly, the weight of 100 grains was notably increased in the stressedinoculated plants with the two PGPB by $67 \%$ than in the uninoculated-stressed ones (D). Moreover, the inoculation with $A$. brasilense NO40 significantly promoted the percentage of grain filling by $6 \%$, the weight of spike by $23 \%$, the weight of grain /spike by $22 \%$ and the weight of 100 grains by $10 \%$ under normal conditions than that of the uninoculated control.

Table 2. Effect of bacterial inoculation with $A$. brasilense $\mathrm{NO} 40\left(\mathrm{~B}_{1}\right)$ and $S$. maltophilia $\left(\mathrm{B}_{2}\right)$ on the yield criteria of Triticum aestivum (cv. 'G9') plants grown in sandy soil, under unstressed (irrigated every 5 days) and drought-stressed (irrigated every 10 days) conditions. Treatments means of 3 sets, each set contained 3 replicas $( \pm \mathrm{SD})$. Cont. $=$ the unstressed-uninoculated treatment; $\mathrm{D}=$ drought-stressed-uninoculated treatment, $\mathrm{B}(1-2)=$ the unstressed-inoculated treatments and DB (1-2) = the drought stressed-inoculated treatments.

\begin{tabular}{|c|c|c|c|c|c|}
\hline Treatment & $\begin{array}{c}\text { \% spike formation/ } \\
\text { pot }\end{array}$ & $\begin{array}{c}\text { Spike weight } \\
(\mathrm{g})\end{array}$ & $\begin{array}{c}\text { \% grain } \\
\text { filling/plant }\end{array}$ & $\begin{array}{c}\text { Grains weight/ } \\
\text { spike }(\mathrm{g})\end{array}$ & $\begin{array}{c}\text { Weight of } 100 \\
\text { grains }(\mathrm{g})\end{array}$ \\
\hline Control & $100 \pm 0.0^{\mathrm{a}}$ & $0.53 \pm 0.01^{\mathrm{b}}$ & $89 \pm 2.3^{\mathrm{a}}$ & $0.37 \pm 0.02^{\mathrm{b}}$ & $2.9 \pm 0.06^{\mathrm{b}}$ \\
\hline B1 & $100 \pm 0.0^{\mathrm{a}}$ & $0.65 \pm 0.02^{\mathrm{a}}$ & $96 \pm 1.7^{\mathrm{a}}$ & $0.45 \pm 0.01^{\mathrm{a}}$ & $3.2 \pm 0.07^{\mathrm{a}}$ \\
\hline B2 & $100 \pm 0.0^{\mathrm{a}}$ & $0.57 \pm 0.02^{\mathrm{ab}}$ & $94 \pm 1.6^{\mathrm{a}}$ & $0.39 \pm 0.01^{\mathrm{b}}$ & $3.0 \pm 0.04^{\mathrm{b}}$ \\
\hline D & $86 \pm 3.1^{\mathrm{b}}$ & $0.18 \pm 0.01^{\mathrm{d}}$ & $47 \pm 2.6^{\mathrm{c}}$ & $0.09 \pm 0.01^{\mathrm{e}}$ & $1.5 \pm 0.02^{\mathrm{d}}$ \\
\hline DB1 & $99 \pm 1.7^{\mathrm{a}}$ & $0.36 \pm 0.06^{\mathrm{c}}$ & $79 \pm 2.5^{\mathrm{b}}$ & $0.28 \pm 0.01^{\mathrm{c}}$ & $2.5 \pm 0.20^{\mathrm{c}}$ \\
\hline DB2 & $99 \pm 1.7^{\mathrm{a}}$ & $0.38 \pm 0.05^{\mathrm{c}}$ & $76 \pm 5.2^{\mathrm{b}}$ & $0.21 \pm 0.02^{\mathrm{d}}$ & $2.5 \pm 0.20^{\mathrm{c}}$ \\
\hline
\end{tabular}

Note: Treatments with identical letters are not significant at $\mathrm{P} \leq 0.01$

The carbohydrate content of the yielded grains 
The obtained results revealed that drought stress significantly affected the contents of carbohydrates in the yielded grains of wheat, where it significantly raised the amounts of the direct reducing sugars and sucrose while it notably reduced the starch content of the grains in the uninoculated and inoculated-stressed treatments (Figure 1). In response to drought stress, the direct reducing sugars were increased by 1.8 -fold in the uninoculated treatment $(\mathrm{D})$, and by 3.2 and 2.6 folds in the $\mathrm{B}_{1}$ - and $\mathrm{B}_{2}$ - treated-stressed plants, respectively, in respect to the uninoculated-unstressed control. The sucrose content of the grains was elevated by $77 \%$ in the uninoculated-drought-stressed treatment $(D)$, but the highest amount of sucrose was recorded in the grains of the drought-stressed plants inoculated with $A$. brasilense $\mathrm{NO} 40\left(\mathrm{DB}_{1}\right)$ that were about twice of that in the uninoculated-well-irrigated control. In contrast, the amount of starch in the grains was significantly decreased under stress; where the lowest accumulation of starch was recorded in the uninoculated treatment (D) which was $223 \mathrm{mg} / \mathrm{g}$ DM. Meanwhile, the inoculation of the plants with $B_{1}$ and $B_{2}$ notably enhanced the starch content of grains under stress by 48 and 32\%, respectively, then that of the uninoculated-stressed counterparts (D). Under the well irrigation conditions, the bacterial inoculation increased the carbohydrate contents of grain; as the highest amount of the direct reducing sugars was obtained in the grains of $S$. maltophilia-treated plants $(23 \mathrm{mg} / \mathrm{g} \mathrm{DM}$ ), while treating plants with $A$. brasilense NO40 induced the maximum accumulation of sucrose and starch which were 222 and $530 \mathrm{mg} / \mathrm{g}$ DM, respectively, compared with 18, 150 and $417 \mathrm{mg} / \mathrm{g}$ DM respectively, in their uninoculated counterparts.
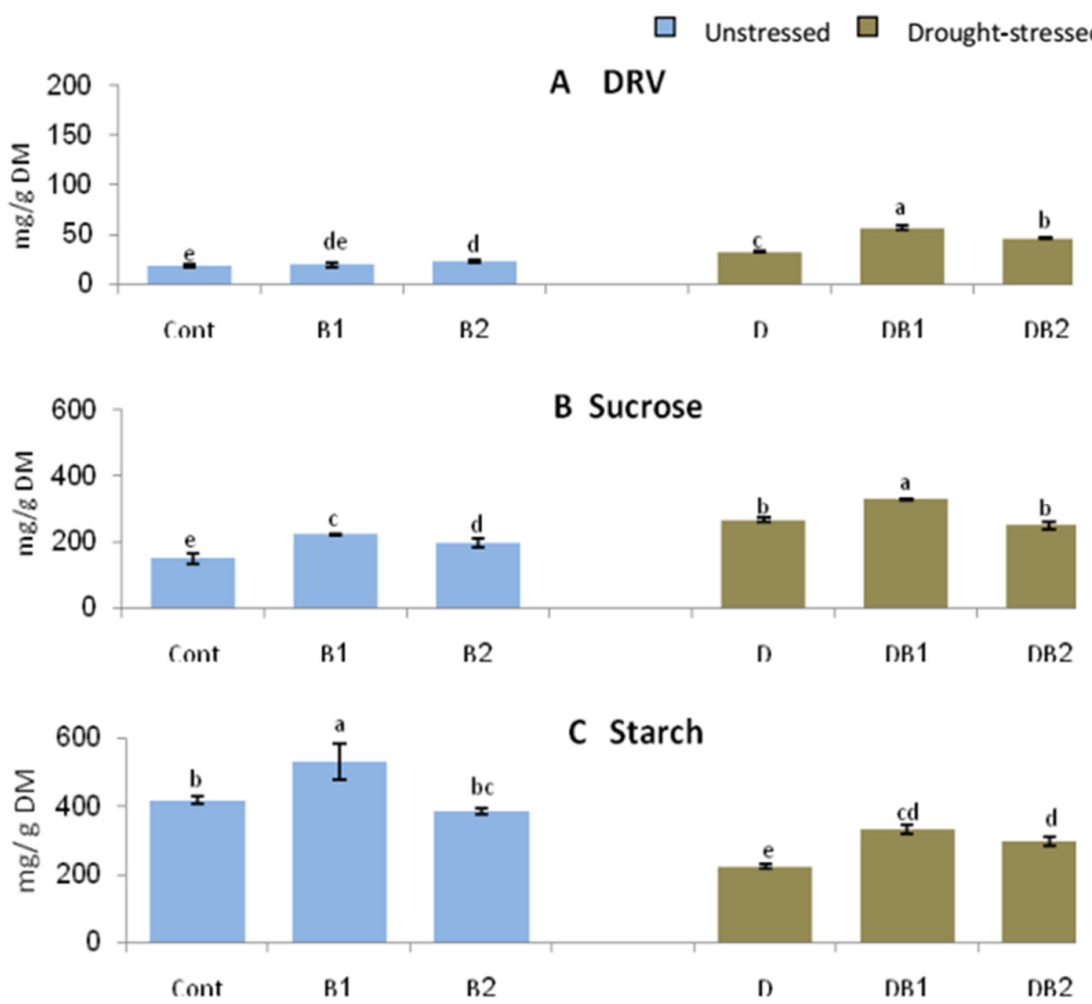

Figure 1. Effect of bacterial inoculation with $A$. brasilense $\operatorname{NO} 40\left(\mathbf{B}_{1}\right)$ and $S$. maltophilia $\left(\mathbf{B}_{2}\right)$ on the contents of total reducing sugars (DRV) (A), sucrose (B) and starch (C) (mg/g DM) of the yielded-grains of Triticum aestivum (cv. G9) plants grown in sandy soil, under unstressed (irrigated every 5 days) and drought-stressed (irrigated every 10 days) conditions. Error bars represent the standard deviation between 3 replicas. Treatments with identical letters are not significant at $\mathrm{P} \leq 0.01$. Cont. $=$ the unstresseduninoculated control; $\mathrm{D}=$ the drought-stressed-uninoculated treatment, $\mathrm{B}(1-2)=$ the unstressedinoculated treatments and $\mathrm{DB}(1-2)=$ the drought-stressed -inoculated treatments

The contents of the total soluble proteins and total free amino acids of the yielded grains 
Generally, the drought stress significantly increased the contents of both of TSPs and TFAAs in the yielded grains of all treatments (Figure 2). The largest increases of TSPs and TFAAs were recorded in the grains of the uninoculated-drought-stressed treatment (D) which were 2.3 and 4.6-fold of that of the well-irrigated control, respectively. Whereas, the yielded grains of the plants treated with $\mathrm{B}_{1}$ and $\mathrm{B}_{2}$ had lower accumulation of TSPs and TFAAs under stress by about 30 and $\geq 35 \%$, respectively than the uninoculated counterpart (D). However, inoculating the unstressed plants with both PGPB slightly raised the amount of total soluble proteins to $42 \mathrm{mg} / \mathrm{g}$ DM compared with $35 \mathrm{mg} / \mathrm{g}$ DM in the uninoculated counterpart. Both bacterial strains notably increased the content of the total free amino acids in the grains of wheat plants. Among the unstressed treatments, the highest content of the TFAA was recorded in the S. maltophilia-treated plants which were $41 \%$ higher than that of the uninoculated control.

\section{Unstressed $\square$ Drought-stressed}
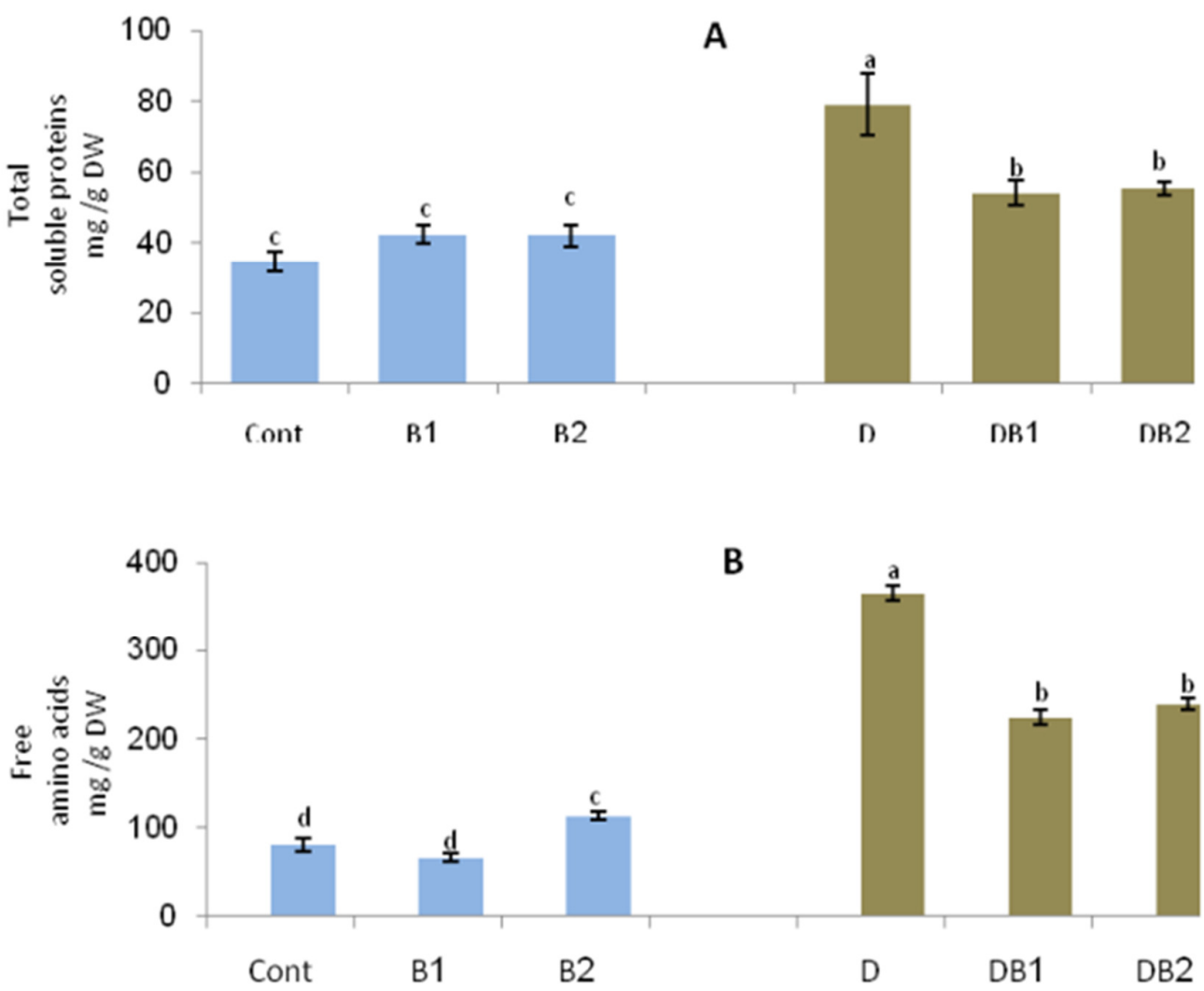

Figure 2. Effect of bacterial inoculation with $A$. brasilense $\mathrm{NO} 40\left(\mathrm{~B}_{1}\right)$ and $S$. maltophilia $\left(\mathrm{B}_{2}\right)$ on the contents of total soluble proteins (A) and total free amino acids (B) (mg/ g DM) of the yielded-grains of Triticum aestivum (cv. G9) plants grown in sandy soil, under unstressed (irrigated every 5 days) and drought-stressed (irrigated every 10 days) conditions. Error bars represent the standard deviation between 3 replicas. Treatments with identical letters are not significant at $\mathrm{P} \leq 0.01$. Cont. $=$ the unstresseduninoculated control; $\mathrm{D}=$ the drought-stressed-uninoculated treatment, $\mathrm{B}(1-2)=$ the unstressedinoculated treatments and $\mathrm{DB}(1-2)=$ the drought-stressed -inoculated treatments 


\section{Protein patterns of the yielded grains}

The molecular masses $(\mathrm{MM})$ of protein patterns shown in Table 3 provide the expression of the effects of drought stress and the inoculation with $B_{1}$ and $B_{2}$ in the yielded grains of wheat.

Table 3. Changes revealed by SDS-PAGE in protein patterns of the yielded-grains of Triticum aestivum (cv. 'G9') plants grown in sandy soil, under unstressed (irrigated every 5 days) and drought stressed (irrigated every 10 days) conditions without and with inoculation with $A$. brasilense $\mathrm{NO} 40\left(\mathrm{~B}_{1}\right)$ and $S$. maltophilia $\left(\mathrm{B}_{2}\right)$

\begin{tabular}{|c|c|c|c|c|c|c|c|}
\hline $\mathrm{M}(\mathrm{Kd})$ & $\mathrm{MM}(\mathrm{Kd})$ & Control & $\mathrm{B}_{1}$ & $\mathrm{~B}_{2}$ & $\mathrm{D}$ & $\mathrm{DB}_{1}$ & $\mathrm{DB}_{2}$ \\
\hline \multirow[t]{3}{*}{250} & & -- & -- & -- & -- & -- & -- \\
\hline & 139 & + & + & + & - & -- & -- \\
\hline & 133 & -- & -- & -- & + & -- & -- \\
\hline \multirow[t]{8}{*}{130} & 130 & -- & -- & -- & -- & + & 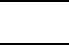 \\
\hline & 129 & -- & -- & -- & -- & - & + \\
\hline & 94 & + & -- & -- & -- & -- & -- \\
\hline & 91 & -- & + & -- & -- & -- & -- \\
\hline & 90 & -- & -- & -- & -- & -- & + \\
\hline & 89 & -- & -- & + & -- & -- & - \\
\hline & 88 & -- & -- & -- & + & -- & -- \\
\hline & 87 & -- & -- & -- & -- & + & -- \\
\hline 95 & & -- & -- & -- & -- & -- & -- \\
\hline \multirow[t]{7}{*}{72} & & -- & -- & -- & -- & -- & -- \\
\hline & 71 & -- & -- & -- & -- & -- & + \\
\hline & 70 & -- & -- & -- & + & + & - \\
\hline & 69 & -- & + & + & -- & -- & -- \\
\hline & 62 & + & -- & -- & - & -- & -- \\
\hline & 59 & -- & -- & -- & -- & -- & + \\
\hline & 56 & -- & -- & -- & + & + & - \\
\hline \multirow[t]{13}{*}{55} & 55 & -- & + & -- & -- & -- & -- \\
\hline & 54 & -- & -- & + & -- & -- & -- \\
\hline & 51 & + & -- & -- & - & -- & -- \\
\hline & 47 & -- & -- & -- & -- & -- & + \\
\hline & 46 & -- & -- & + & + & + & -- \\
\hline & 45 & -- & + & -- & -- & -- & + \\
\hline & 44 & -- & -- & -- & + & -- & -- \\
\hline & 43 & + & -- & -- & $\ldots$ & + & -- \\
\hline & 42 & -- & + & + & -- & -- & -- \\
\hline & 41 & -- & -- & -- & -- & -- & + \\
\hline & 40 & -- & + & + & + & + & -- \\
\hline & 38 & + & -- & -- & $\ldots$ & & + \\
\hline & 37 & -- & + & + & + & + & 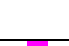 \\
\hline \multirow[t]{3}{*}{36} & 36 & -- & -- & -- & -- & -- & + \\
\hline & 33 & -- & -- & + & -- & -- & -- \\
\hline & 32 & -- & + & -- & + & + & + \\
\hline \multirow[t]{4}{*}{28} & & -- & -- & -- & -- & -- & \\
\hline & 23 & -- & -- & -- & -- & -- & + \\
\hline & 22 & -- & -- & + & + & -- & -- \\
\hline & 20 & -- & + & -- & -- & -- & -- \\
\hline
\end{tabular}

$\mathrm{M}=$ marker; $\mathrm{MM}=$ molecular mass; $+=$ present, $--=$ absent; Cont. $=$ the unstressed and uninoculated control; $\mathrm{D}=$ the drought stressed and uninoculated treatment, $\mathrm{B}(1-2)=$ the unstressed and inoculated treatments and $\mathrm{DB}(1-2)=$ the drought stressed and inoculated treatments 
Data revealed the following:

1)Drought stress induced synthesis of five new proteins bands with MM 133, 88, 70, 56 and 44 in the stressed-uninoculated grains which were not detected in the control or in all of the inoculated-drought stressed seedlings, except for the protein bands with MM 70 and 56 that were also appeared in the grains of $\mathrm{DB}_{1}$ treatment.

2)Drought induced the disappearance of six polypeptides having $M M$ of $139,94,62,51,43$ and $38 \mathrm{KDa}$, which were detected in the control. The inoculation returned some of them, as the bands with MM 43 and 38 $\mathrm{KDa}$ which reappeared in the $\mathrm{DB}_{1}$ and $\mathrm{DB}_{2}$ treatments, respectively

3) On the other hand, the bacterial inoculation not only relieved the deleterious impact of drought stress through the re-appearance of some bands which disappeared under drought stress, but also by the induction of newly synthesized bands, such as: the bands with $\mathrm{MM} 130$ and $87 \mathrm{KDa}$ in $\mathrm{DB}_{1}$ and 129, 90, 71, 59, 47, 41, 36 and $23 \mathrm{kDa}$ in $\mathrm{DB}_{2}$ treatments which were undetected in the control or in the corresponding uninoculateddrought-stressed counterparts.

4) Under normal conditions, the bacterial inoculation resulted in newly synthesized proteins as the bands with MM 91, 55 and $20 \mathrm{KDa}$ appeared only in A. brasilense NO40-inoculated plants and the bands with MM 89, 54, and 33 appeared only in S. maltophilia-treated plants, while the bands have MM 69 and $42 \mathrm{KDa}$ appeared with both microbes.

\section{Discussion}

Crop yield is the final outcome of complexly interrelated crop growth and development processes strongly affected by water availability (Farooq et al., 2009; Fahad et al., 2017). The results showed that the drought stress resulted in harsh effect on wheat yield as indicated from the significant reductions in the all measured criteria of yield (spike formation\%, weight of spike, grain filling\%, weight of grains/spike and weight of 100 grains). These results are in conformity with those obtained by Darkwa et al. (2016) on Vicia faba. The drought-mediated decline in crop yields can be ascribed to various factors, especially those mainly determining the source and sink capacity (Blum, 2011; Wang et al., 2017). This reduction in yield parameters under drought stress may be due to the premature leaf senescence, oxidation of chloroplast lipids and alterations in the assembly of pigments and proteins, leading to lowering the supply of carbon assimilate, reduced photosynthetic rate and consequently minimal biomass production, as well as diminished translocation of assimilates towards the developing seeds (Abid et al., 2016; Kasim et al., 2017). Wang et al. (2017) conducted a meta-analysis of 303 papers published before May 2015 studying the effects of drought stress on the morpho-physiological and biochemical characteristics, growth and biomass partitioning, and yield formation of diploid, tetraploid, and hexaploid wheat. This analysis indicated that the yield losses from drought stress significantly correlated to: 1) the reduction in the leaf area (as a key driver), the whole-plant assimilation rate, and leaf chl-a and b; 2) arrest in organs' differentiation and/or dysfunction of the differentiated reproductive organs (e.g. the number of flowers can be reduced by arrested differentiation or by abortion and deterioration of developed flowers under stress, while the declined number of grains developed from a given number of flowers can be a result of the stress-induced sterility of female or male organs, abortion of embryos (Blum, 2011) and/or the decrease of the endosperm cell number and metabolic activity; and greatly to 3) the disturbance in the resources' allocation and reallocation patterns.

The present study also reveals that the yielded grains under drought stress had lower content of starch and higher contents of the reducing sugars, sucrose, the total soluble proteins (TSPs) and the total free amino acids (TFAAs) in addition to having altered protein patterns than those of the unstressed plants. These results agreed with those of Qudsia et al. (2013) for maize. The total soluble protein content of the yielded seeds in the present results revealed a highly significant increase with drought, which was similar to the trend previously obtained in the vegetative stage reported by Kasim et al. (2017). This increase may be due to the induction of 
stress proteins, which are particularly involved in the maintenance of cell redox and might act as antioxidant enzymes (Shu et al., 2012).

Drought can often cause significant metabolism alteration in plants, for instance, the altered carbohydrates contents (reduced starch and increased sugars) which can be a result of: 1) declined starch production due to the reduced assimilate supply or the altered activities of the biosynthetic enzymes; or 2) enhanced starch degradation to sugars, as sugars can act as signaling and regulatory molecules; energy and carbon building blocks of protective proteins and compounds; and as compatible solutes, osmotic spacers, and ROS scavengers in order to increase cell turgor and to protect sensitive membranes and proteins (Thitisaksakul et al., 2012; Dong and Beckles, 2019). Likewise, the increased levels of the free amino acids could be a result of diminished synthesis or increased breakdown of specific proteins, while other proteins (namely stress-induced proteins) may be induced or up-regulated (Farooq et al., 2009; Aslam et al., 2015; Ghatak et al., 2017).

On the other hand, treating wheat plants with $A$. brasilense $\mathrm{NO} 40$ or $S$. maltophila under drought stress significantly enhanced almost all their measured yield parameters, where the yielded grains had significantly higher contents of carbohydrates (the direct reducing sugars, sucrose and starch); lower amounts of total soluble proteins and the total free amino acids; and altered protein patterns compared with the uninoculated stressed treatments. Furthermore, under normal conditions, inoculating wheat plants with PGPB resulted in significantly improved yields with higher contents of carbohydrates, than those of the uninoculated control. These results agreed with those of Askary et al. (2009) and of Creus et al. (2004) who stated that even in stress conditions, Azospirillum inoculation increased the grain yield and mineral nutrition in plants under stress.

Five of the Heat Shock Protein families (HSPs) with MM ranging between $250 \mathrm{kDa}$ and $15 \mathrm{kDa}$ with roles to play in combating abiotic stresses in plants are represented in our study. Thus, the protein bands with MM $133 \mathrm{kDa}$ may function as HSP 100 which play a crucial role in re-solubilizing protein aggregates via interactions with the sHSP chaperone system (Bosl et al., 2006). The protein band with MM $88 \mathrm{kDa}$, may function as HSP 90 and regulates protein folding and plays a key role in signal transduction networks, protein degradation and protein trafficking (Park and Seo, 2015). The protein band with MM $70 \mathrm{kDa}$, belongs to HSP 70 and acts as a chaperone for newly synthesized proteins to prohibit their accumulation as aggregates as well as to maintain proper protein folding through their transfer to their final location (Park and Seo, 2015). The protein bands with MM $56 \mathrm{kDa}$ are members of the HSP 60 family which help in protein folding and subunit assembly (Efeoglu, 2009). The protein bands with MM $44 \mathrm{kDa}$ of the HSP40 family are known to induce HSP70 affinity for clients (Kampinga and Craig, 2010).

Taken together our previous studies in which Azospirillum brasilense NO40 and Stenotrophomonas maltophilia had enhanced the growth and performance of wheat seedlings under drought stress (Kasim et al., 2013; Omar et al., 2017) with the current results, we can assume that the uninoculated wheat plants showed a relatively low degree of drought tolerance, and may have favored survival over growth by maintaining highly activated defenses that had resulted in high deleterious effect on growth and productivity, unlike the inoculated plants that showed a relatively higher degree of drought tolerance by which they were able to deactivate the growth inhibition to some extent while maintaining a certain level of efficient protection against damage, which finally translated into higher yields under drought stress.

The augmented yield production and crop quality under both normal irrigation and drought stress conditions was reported in many plants treated with PGPB (Ngumbi and Kloepper, 2016; Etesami and Maheshwari, 2018). For instance, Treating plants with PGPB has been reported to: 1) induce favorable alterations in root growth and architecture (longer roots, longer and denser lateral roots and higher biomasses) (Naseem and Bano, 2014; Timmusk et al., 2014); 2) improve shoot growth (higher shoots and heavier biomasses) (Kasim et al., 2013; Grover et al., 2014); 3) maintain relatively higher relative water contents than the drought-stressed and bacterially-untreated plants (Sandhya et al., 2010; Naveed et al., 2014; Naseem and Bano, 2014); 4) facilitate water and nutrient (e.g. Fe, P and N) acquisition (Desai et al., 2012; Ngumbi and Kloepper, 2016); 5) modulate the plant hormones levels either by synthesizing phytohormones or by lowering 
the plant-produced ethylene via the ACC-deaminase activity (Castillo et al., 2013; Bresson et al., 2013; Ngumbi and Kloepper, 2016); 6) stabilize membranes (Gusain et al., 2015); and 7) regulate each of expression of some drought-triggered genes (Kasim et al., 2013; Sarma and Saikia, 2014), production of osmolytes (Bano et al., 2013; Gururani et al., 2013), and activities of different enzymes (Kohler et al., 2008) resulting in promoted plant growth and productivity under drought stress (Vurukonda et al., 2016; Forni et al., 2017). Moreover, inoculating the salt-stressed barely with $A$. brasilense NO40 significantly ameliorated the adverse effect of salinity on growth and yield (Omar et al., 2009), but no available studies illustrating the role of $S$. maltophila in augmenting crop yields under abiotic stressed conditions.

However, the exact mechanisms by which the selected PGPB maintained and integrated their multiple plant growth traits to achieve their positive impact on the overall performance of wheat plants under drought stress remain largely speculative (Ngumbi and Kloepper, 2016; Forni et al., 2017). However, it is known that the PGPB have the ability to induce systemic tolerance by triggering several physical and chemical changes in plants that result in enhanced tolerance to abiotic stresses (Yang et al., 2009). One or both of the following explanations can be postulated to explain the way in which this tolerance was attained in the present study:

1) The first explanation is that: priming and coating wheat grains with PGPB might have induced acclimation. It has been shown that certain beneficial microbes can pose some biotic stress on plant, that in turn activate the plant defensive metabolism before the stress onset, resulting in better or more rapidly mount defense responses, or both, to biotic or abiotic stress " the plant primed state" (Conrath et al., 2006; RajendraPrasad et al., 2016). The previous results of the less activated defenses (Salama, 2019) may imply that PGPB application enhanced the adaptation responses, rather than their direct activation as is the case in acclimation treatments in which plants are gradually exposed to an increasing stress situation. It is worth-noting that the less activated defenses may suggest that the inoculated plants were able to avoid the heavy consumption of resources for defense, and therefore maintained better growth and here better yield than the uninoculated plants.

2) The second explanation is that: the introduced PGPB might have earlier sensed the imposed stress and responded to it, because they are small, in intimate contact with soil water, and have semipermeable membranes (Schimel et al., 2007), and accordingly, they might have affected the plant metabolism. For instance, it is known that soil microbes have the ability to influence rhizodeposition, not only respond to it (Phillips et al., 2004). Likewise, it can be assumed that somehow the introduced PGPB could have provided some kind of early warning to the plant to be prepared to cope well with the imposed stress. This can be supported by the ability of both microbes to produce $\mathrm{ABA}$ and the possibility of being able to produce or trigger other alarming volatiles or compounds.

\section{Conclusions}

It seems reasonable to conclude that treating wheat plants with the PEG-tolerant Azospirillum brasilense NO40 or Stenotrophomonas maltophilia which possess multiple plant growth promoting traits and were compatible with systems into which they were introduced, can offer a promising, feasible and sustainable strategy to enhance wheat growth and productivity, not only under normal conditions, but also under drought stress. Accordingly, it is strongly recommended that farmers and agriculture companies in Egypt inoculate wheat grains and plants with such PGPB as Azospirillum brasilense NO40 and S. maltophilia as a means of combating drought stress. In practice, Azospirillum brasilense NO40 is already available and licensed by the Egyptian Ministry of Agriculture for inoculating wheat cultivated under drought stress conditions in sandy soils. 


\section{Acknowledgements}

This research received no specific grant from any funding agency in the public, commercial, or not-forprofit sectors.

\section{Conflict of Interests}

The authors declare that there are no conflicts of interest related to this article.

\section{References}

Abid G, M'hamdi M, Mingeot D, Aouida M, Aroua I, Muhovski Y, ... Jebara M (2016). Effect of drought stress on chlorophyll fluorescence, antioxidant enzyme activities and gene expression patterns in faba bean (Vicia faba L.). Archives of Agronomy and Soil Science 63:536-552.

Askary M, Mostajeran A, Amooaghaei R, Mostajera M (2009). Influence of the co-inoculation Azospirillum brasilense and Rhizobium melilotiplus 2,4-D on grain yield and N, P, K Content of Triticum aestivum (cv. Baccros and Mahdavi). American-Eurasian Journal of Agricultural \& Environmental Sciences 5(3):296-307.

Aslam M, Maqbool MA, Cengiz R (2015). Mechanisms of drought resistance. In: Drought stress in maize (Zea Mays L.). Springer briefs in agriculture. Springer, Cham, Heidelberg, New York Dordrecht, London pp 19-36.

Bano Q, Ilyas N, Bano A, Zafar N, Akram A, Hassan F (2013). Effect of Azospirillum inoculation on maize (Zea mays L.) under drought stress. Pakistan Journal of Botany 45:13-20.

Blum A (2011). Drought resistance and its improvement. In: plant breeding for water-limited environments. Springer New York, New York pp 53-152.

Bosl B, Grimminger V, Walter S (2006). The molecular chaperone Hsp104--a molecular machine for protein disaggregation. Journal of Structural Biology 156:139-148.

Bradford M (1976). A rapid and sensitive method for the quantitation of microgram quantities of protein utilizing the principle of protein-dye binding. Analytical Biochemistry 72:248-258.

Bresson J, Varoquax F, Bontpart T, Touraine B, Vile D (2013). The PGPR strain Phyllobacterium brassicacearum STM 196 induces a reproductive delay and physiological changes that result in improved drought tolerance in Arabidopsis. New Phytologist 200:558-569.

Castillo P, Escalante M, Gallardo M, Alemano S, Abdala G (2013). Effects of bacterial single inoculation and coinoculation on growth and phytohormone production of sunflower seedlings under water stress. Acta Physiologiae Plantarum 35:2299-2309.

Claeys H, Van Landeghem S, Dubois M, Maleux K, Inze D (2014). What is stress? Dose-response effects in commonly used in vitro stress assays. Plant Physiology 165:519-527.

CoHort software. (1998). CoStat Statistical Software (6,3). California, USA.

Conrath U, Beckers G, Flors V, García-Agustín P, Jakab G, Mauch F, ... Mauch-Mani B (2006). Priming: getting ready for battle. Molecular Plant-Microbe Interactions 19:1062-1071.

Creus CM, Sueldo RJ, Barassi CA (2004). Water relations and yield in Azospirillum inoculated wheat exposed to drought in the field. Canadian Journal of Botany 82:273-281.

Damania R, Desbureaux S, Hyland M, Islam A, Moore S, Rodella AS, ... Zaveri E (2017). Uncharted waters: the new economics of water scarcity and variability. World Bank, Washington DC.

Darkwa K, Ambachew D, Mohammed H, Asfaw A, Blair MW (2016). Evaluation of common bean (Phaseolus vulgaris L.) genotypes for drought stress adaptation in Ethiopia. The Crop Journal 4:367-376.

Daryanto S, Wang L, Jacinthe PA (2017). Global synthesis of drought effects on cereal, legume, tuber and root crops production: A review. Agricultural Water Management 179:1833.

De Leonardis AM, Mastrangelo AM, Petrarulo M, De Vita P (2012). Genetic and molecular aspects of plant response to drought in annual crop species. In: Advances in selected plant physiology aspects. (Eds) Montanaro G. and Dichio B. In Tech, Rijeka, Croatia pp 45-73. 
Desai S, Grover M, Amalraj ELD, Kumar GP, Ahmed SKMH (2012). Exploiting plant growth promoting rhizomicroorganisms for enhanced crop productivity. In: Microorganisms in sustainable agriculture and biotechnology (Eds) Prakash A, Satyanarayana T, Johri BN Springer Netherlands, Dordrecht pp 227-241.

Dong S, Beckles DM (2019). Dynamic changes in the starch-sugar interconversion within plant source and sink tissues promote a better abiotic stress response. Journal of Plant Physiology 234(235):80-93.

Efeoglu B (2009). Heat shock proteins and heat shock response in plants. Gazi University Journal of Science 22(2):6775.

El-Shami MEM, Abdel-Karim AA, Hanna NS, Towfelis MB, Tammam AM, Gedan MK, ... Ashoush HA (2000). Gemmiza 9: a new Egyptian high yielding and rust resistant bread wheat cultivar for Delta region. Journal of Agricultural Science, Mansoura University 25:7407-7419.

Etesami H, Maheshwari DK (2018). Use of plant growth promoting rhizobacteria (PGPRs) with multiple plant growth promoting traits in stress agriculture: Action mechanisms and future prospects. Ecotoxicology and Environmental Safety 156:225-246.

Fahad S, Bajwa AA, Nazir U, Anjum SA, Farooq A, Zohaib A... Huang J (2017). Crop production under drought and heat stress: plant responses and management options. Frontiers in Plant Science 8:1-16.

FAO (2015). National Investment Profile: Water for Agriculture and Energy (Egypt). Rome, Italy.

FAO and EBRD (2015). Egypt: Wheat Sector Review. Food and Agriculture Organization of the United Nations, Rome, Italy.

FAO-Aquastat (2018). Retrieved from FAO-Aquastat database: Country Profile: Egypt: Retrieved at 22 November 2017 from http://www.fao.org/nr/water/aquastat/countries_regions/EGY/

Farooq M, Wahid A, Kobayashi N, Fujita D, Basra SMA (2009). Plant drought stress: effects, mechanisms and management. Agronomy for Sustainable Development 29:185-212.

FAS/USDA (2018). Grain: world markets and trade. United States Department of Agriculture Foreign Agricultural Service.

Forni C, Duca D, Glick BR (2017). Mechanisms of plant response to salt and drought stress and their alteration by rhizobacteria. Plant and Soil 410:335-356.

Ghatak A, Chaturvedi P, Weckwerth W (2017). Cereal crop proteomics: systemic analysis of crop drought stress responses towards marker-assisted selection breeding. Frontiers in Plant Science 8:757.

Grover M, Madhubala R, Ali SZ, Yadav SK, Venkateswarlu B (2014). Influence of Bacillus spp. strains on seedling growth and physiological parameters of sorghum under moisture stress conditions: Bacillus spp. strains influence sorghum under moisture stress. Journal of Basic Microbiology 54:951-961.

Gururani MA, Upadhyaya CP, Baskar V, Venkatesh J, Nookaraju A, Park SW (2013). Plant growth-promoting rhizobacteria enhance abiotic stress tolerance in Solanum tuberosum through inducing changes in the expression of ROS-scavenging enzymes and improved photosynthetic performance. Journal of plant growth regulation 32:245-258.

Gusain YS, Singh US, Sharma AK (2015). Bacterial mediated amelioration of drought stress in drought tolerant and susceptible cultivars of rice (Oryza sativa L.). African Journal of Biotechnology 14:764-773.

Kampinga HH, Craig EA (2010). The HSP70 chaperone machinery: J proteins as drivers of functional specificity. Nature Reviews Molecular Cell Biology 11:579-592.

Kasim WA, Nessem AA, Gaber A (2017). Alleviation of drought stress in Vicia faba by seed priming with ascorbic acid or extracts of garlic and carrot. The 7th Inter. Conf. "Plant \& Microbial Biotech. \& their Role in the Development of the Society". Egyptian Journal of Botany 45-59.

Kasim WA, Osman ME, Omar MN, Abd El-Daim IA, Bejai S, Meijer J (2013). Control of drought stress in wheat using plant-growth-promoting bacteria. Journal of plant growth regulation 32:122-130.

Kohler A, Hernândez JA, Caravaca F, Roldân A (2008). Plant-growth-promoting rhizobacteria and arbuscular mycorrhizal fungi modify alleviation biochemical mechanisms in water-stressed plant. Functional Plant Biology 35:141-151.

Laemmli UK (1970). Cleavage of structural proteins during the assembly of the head of bacteriophage T4. Nature 227:680-685.

Lee YP, Takahashi T (1966). An improved colorimetric determination of amino acids with the use of ninhydrin. Analytical Biochemistry 14:71-73.

Mekonnen M, Hoekstra A (2016). Four billion people facing severe water scarcity. Science Advances 2:1-7. 
MSEA (2010). The Second National Communication of Egypt under the United Nations Framework Convention on Climate Change (UNFCCC). Egyptian Environmental Affairs Agency (EEAA). Ministry of State for Environmental Affairs (MSEA), Cairo, Egypt.

MWRI (2014). Water scarcity in Egypt: the urgent need for regional cooperation among the Nile basin countries. Technical Report, Ministry of Water Resources and Irrigation, Cairo, Egypt.

Naguib M (1963). Colorimetric estimation of plant polysaccharides. Zucker 16:115-118.

Naseem H, Bano A (2014). Role of plant growth-promoting rhizobacteria and their exopolysaccharide in drought tolerance of maize. Journal of Plant Interactions 9:689-701.

Naveed M, Mitter B, Reichenauer TG, Wieczorek K, Sessitsch A (2014). Increased drought stress resilience of maize through endophytic colonization by Burkholderia phytofirmans PsJN and Enterobacter sp. FD17. Environmental and Experimental Botany 97:30-39.

Nelson N (1944). A photometric adaptation of some methods for the determination of glucose. Journal of Biological Chemistry 153:375-381.

Ngara R, Ndimba BK (2014). Understanding the complex nature of salinity and drought-stress response in cereals using proteomics technologies. Proteomics 14:611-621.

Ngumbi E, Kloepper J (2016). Bacterial-mediated drought tolerance: current and future prospects. Applied Soil Ecology 105:109-125.

OED/FAO (2018). Country program evaluation series: evaluation of FAO's contribution to the Arab Republic of Egypt (2012-2017). Rome, Italy.

Omar AMN, Richard Cl, Weinhard P, Balandreau J (1989). Using the spermosphere model technique to describe the dominant nitrogen-fixing microflora associated with wetland rice in two Egyptian soils. Biology and Fertility of Soils 7:158-163.

Omar MN, Osman ME, Kasim WA, Salama S (2017). Characterization of two drought-tolerant PGPB:Azospirillum brasilense NO40 and Stenotrophomonas maltophilia. Journal of Environmental Sciences 46:121-136.

Omar MNA, Osman MEH, Kasim WA, El-Daim IA (2009). Improvement of salt tolerance mechanisms of barley cultivated under salt stress using Azospirillum brasilense. In: Salinity and water stress. Tasks for vegetation sciences. (eds: Ashraf M., Ozturk M., Athar H.). vol 44. Springer, Dordrecht pp 133-147.

Park CJ, Seo YS (2015). Heat shock proteins: a review of the molecular chaperones for plant immunity. Plant Pathology Journal 31(4):323-333.

Phillips DA, Fox TC, King MD, Bhuvaneswari TV, Teuber LR (2004). Microbial products trigger amino acid exudation from plant roots. Plant Physiology 136:2887-2894.

Qudsia B, Ilyas N, Bano A, Zafar N, Akram A, Ul Hassan F (2013). Effect of Azospirillum inoculation on maize (Zea mays L.) under drought stress. Pakistan Journal of Botany 45(S1):13-20.

Rajendra-Prasad S, Kamble UR, Sripathy KV, Udaya-Bhaskar K, Singh DP (2016). Seed bio-priming for biotic and abiotic stress management. In: microbial inoculants in sustainable agricultural productivity. (eds: Singh D. P., Singh H. B., Prabha R.). Springer India, New Delhi pp 211-228.

Salama S (2019). Enhancement of drought tolerance in Triticum aestivum using plant growth promoting rhizobacteria. Msc. Thesis, Faculty of Science, Tanta Univ, Tanta, Egypt.

Sandhya V, Ali SZ, Grover M, Reddy G, Venkateswarlu B (2010). Effect of plant growth promoting Pseudomonas spp. on compatible solutes, antioxidant status and plant growth of maize under drought stress. Plant growth Regulation 62:21-30.

Sarma R, Saikia R (2014). Alleviation of drought stress in mung bean by strain Pseudomonas aeruginosa GGRJ21. Plant and Soil 377:111-126.

Schimel J, Balser TC, Wallenstein M (2007). Microbial stress-response physiology and its implications for ecosystem function. Ecology 88:1386-1394.

Shu X, Yin L, Zhang Q, Wang W (2012). Effect of Pb toxicity on leaf growth, antioxidant enzyme activities, and photosynthesis in cuttings and seedlings of Jatropha curcas L. Environmental Science and Pollution Research 19:893-902.

Singh JS, Singh DP (2013). Plant Growth Promoting Rhizobacteria (PGPB): microbes in sustainable agriculture. In: Management of microbial resources in the environment. Malik A, Grohmann E, Alves M (Eds). Springer Netherlands, Dordrecht pp 361-385. 
Thitisaksakul M, Jiménez RC, Arias MC, Beckles DM (2012). Effects of environmental factors on cereal starch biosynthesis and composition. Journal of Cereal Science 56:67-80.

Timmusk S, Abd El-Daim IA, Copolovici L, Tanilas T, Kännaste A, Behers L, ... Niinemets Ü (2014). Drought-tolerance of wheat improved by rhizosphere bacteria from harsh environments: enhanced biomass production and reduced emissions of stress volatiles. PLOS ONE 9:1-13.

Vurukonda SSKP, Vardharajula S, Shrivastava M, SkZ A (2016). Enhancement of drought stress tolerance in crops by plant growth promoting rhizobacteria. Microbiological Research 184:13-24.

Wang JY, Xiong YC, Li FM, Siddique KHM, Turner NC (2017). Effects of drought stress on morphophysiological traits, biochemical characteristics, yield, and yield components in different ploidy wheat: a meta-analysis. In: Advances in agronomy (Eds) Sparks DL. Academic Press pp 139-173.

WB (2017). Beyond scarcity: water security in the Middle East and North Africa. MENA development series. World Bank, Washington, DC. License: Creative Commons Attribution CC BY 3.0 IGO.

WFP/EB (2018). Draft: Egypt country strategic plan (2018-2023). Annual session (June, 2018). Rome, Italy. Yang J, Kloepper JW, Ryu C (2009). Rhizosphere bacteria help plants tolerate abiotic stress. Trends in Plant Science 14:14.
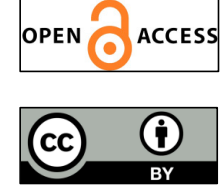

The journal offers free, immediate, and unrestricted access to peer-reviewed research and scholarly work. Users are allowed to read, download, copy, distribute, print, search, or link to the full texts of the articles, or use them for any other lawful purpose, without asking prior permission from the publisher or the author.

License - Articles published in Notulae Scientia Biologicae are Open-Access, distributed under the terms and conditions of the Creative Commons Attribution (CC BY 4.0) License.

(c) Articles by the authors; SHST, Cluj-Napoca, Romania. The journal allows the author(s) to hold the copyright/to retain publishing rights without restriction. 